\title{
Intake of copper, iron, manganese and zinc by healthy, exclusively-breast-fed infants during the first 3 months of life
}

\author{
BY E. VUOR I \\ Department of Public Health Science, University of Helsinki, \\ Haartmaninkatu 3, SF-00290 Helsinki 29, Finland
}

(Received 8 May 1979-Accepted 31 May 1979)

\begin{abstract}
I. The calculated median daily trace element intakes $/ \mathrm{kg}$ of exclusively-breast-fed infants at $\mathrm{I}, 2$ and 3 months of age respectively were: copper $0.075,0.05 \mathrm{I}$ and $0.043 \mathrm{mg}$; iron $0.075,0.055$ and $0.048 \mathrm{mg}$; manganese $0.9,0.6$ and $0.5 \mu \mathrm{g}$; zinc $0.420,0.215$ and $0.150 \mathrm{mg}$. The latter values for $\mathrm{Cu}, \mathrm{Fe}$, and $\mathrm{Zn}$ intakes were in good agreement with earlier results, whereas the intake of $\mathrm{Mn}$ was lower. The intakes of trace elements by breast-fed infants seemed to be below the recommended dietary allowances (Food and Nutrition Board, 1973; WHO Expert Committee on Trace Elements in Human Nutrition, 1973).

2. There seems to be no information on trace element concentrations of breast milk related to the energy content. Such values are therefore included for breast milk from Finnish women for the ist 6 months of lactation.
\end{abstract}

The food intake of infants fed with formulas containing different densities of energy is regulated by the energy content rather than by the volume ingested (Fomon, 1974). It is more likely that food intake in breast-fed infants might be controlled by increasing fat content during a single feed, which might be an additional mechanism in the regulation (Hall, 1975). Moreover, it has been shown that there is an inverse correlation between the daily volume of breast milk and its total content of fat, thus suggesting constant energy intake (Hytten, I954). The energy and trace element contents of breast milk have been shown to vary among mothers (Fomon, 1974; Siimes et al. 1979; Vuori, 1979; Vuori \& Kuitunen, 1979; Vuori, Kuitunen \& Salmela, unpublished results). Thus the low concentration of trace elements in breast milk does not necessarily mean low intake. Studies on the trace element intake of exclusively-breast-fed, healthy infants are not numerous (Maurer et al. 1934; Kleinbaum, 1962; Cavell \& Widdowson, I964; McLeod \& Robinson, 1972; Picciano \& Guthrie, 1976; Picciano \& Deering, 1977). The results of such studies, however, ought to serve as a guide when the trace element requirements for infants are estimated. The present study gives the calculated average intakes of copper, iron, manganese and zinc of exclusively-breast-fed infants during the ist 3 months of life. In general, these intakes are in good agreement with earlier results obtained using different methods, but the intake of $\mathrm{Mn}$ is lower. The intake of trace elements by breast-fed infants seems to be below the recommended dietary allowances (Food and Nutrition Board, 1973; WHO Expert Committee on Trace Elements in Human Nutrition, 1973).

\section{SUBJECTS AND METHODS}

A group of twenty-seven full-term healthy infants was studied from birth. All infants were exclusively breast-fed, apart from water (from birth), vitamin D concentrate (from 2 to 3 weeks of age) and diluted fruit juice (from 6 to 8 weeks of age). The number of infants, entirely on breast milk, declined with increasing stage of lactation and was twenty-three at the Ist month, eighteen at the 2 nd month and fourteen at the 3 rd month. Details of the volunteer lactating mothers and method of collecting milk samples have been described earlier (Vuori \& Kuitunen, 1979). The growth of the infants was checked regularly at the communal child health centres, where the height and weight were recorded by experienced 
Table $\mathrm{I}$. The weight $(\mathrm{kg})$, height $(\mathrm{m})$ and number of exclusively-breast-fed Finnish boys and girls at birth and at $\mathrm{I}, 2$ and 3 months of age

\begin{tabular}{|c|c|c|c|c|c|}
\hline & & & & nth of & \\
\hline & & Birth & ist & 2nd & 3 rd \\
\hline Boys & & & & & \\
\hline $\mathrm{Wt}$ & Mean & $3 \cdot 53$ & $4 \cdot 16$ & 5.02 & $5 \cdot 76$ \\
\hline & & 0.32 & 0.38 & 0.59 & 0.88 \\
\hline Height & Mean & 0.500 & 0.545 & $0.58 i$ & 0.611 \\
\hline & SD & 0.013 & 0.021 & 0.026 & 0.029 \\
\hline$n$ & & 13 & 12 & 9 & 7 \\
\hline Girls & & & & & \\
\hline Wt & Mean & 3.58 & $4 \cdot 17$ & 4.99 & $5 \cdot 66$ \\
\hline & SD & 0.39 & 0.21 & 0.33 & 0.44 \\
\hline Height & Mean & 0.501 & 0.553 & 0.582 & 0.611 \\
\hline & SD & 0.016 & 0.013 & 0.016 & 0.015 \\
\hline$n$ & & 14 & II & 9 & 7 \\
\hline
\end{tabular}

Table 2. The median copper, iron, manganese and zinc concentrations of breast milk from Finnish women $(\mu \mathrm{g} / 100 \mathrm{~kJ}$ available $)$ during 6 months lactation*

$\begin{array}{cccccr}\begin{array}{c}\text { Stage of lactation } \\ \text { (weeks) }\end{array} & n & \mathrm{Cu} & \text { Fe } & \text { Mn } & \text { Zn } \\ 2 & 20 & 20.8 & 20.9 & 0.22 & \text { I4I } \\ 3 & 23 & 17.8 & 18.4 & 0.21 & 103 \\ 4 & 21 & 16.6 & 17.1 & 0.19 & 90 \\ 5 & 23 & 14.0 & 14.1 & 0.17 & 84 \\ 6 & 15 & 13.9 & 15.2 & 0.16 & 80 \\ 7 & 15 & 12.4 & 12.9 & 0.14 & 61 \\ 8-10 & 18 & 12.4 & 13.4 & 0.14 & 48 \\ 11-13 & 16 & 11.1 & 12.3 & 0.13 & 40 \\ 14-16 & 10 & 9.0 & 11.6 & 0.15 & 34 \\ 17-19 & 12 & 8.3 & 10.8 & 0.14 & 25 \\ 20-22 & 12 & 7.9 & 9.5 & 0.11 & 25 \\ 23-25 & 10 & 6.1 & 9.1 & 0.13 & 16 \\ 26-28 & 8 & 7.7 & 10.3 & 0.15 & 17\end{array}$

* Values recalculated from results of previous studies (Siimes et al. 1979; Vuori, 1979; Vuori \& Kuitunen, 1979).

nurses. Individual growth curves were prepared for each infant. The exact weight and height corresponding to the ages of 1,2 and 3 months were obtained from these curves.

The determination of the energy and trace element concentration of the breast-milk samples has been described elsewhere (Siimes et al. 1979; Vuori, 1979; Vuori \& Kuitunen, I 979; Vuori, Kuitunen \& Salmela, unpublished results). For each mother individual curves were prepared for the variation in the energy and trace element concentration of her milk. The actual values during the ist, 2 nd and 3 rd month of lactation were estimated from these values.

The trace element intakes were calculated on the basis of the known energy requirement of normally-growing, healthy infants of different ages. The average intake of energy $(\mathrm{kJ} / \mathrm{kg}$ per d) was taken from the studies of Fomon (1974), and was at 1,2 and 3 months of age 464,406 and 393 for girls and 485,418 and 402 for boys respectively. 
Table 3. The intake of copper, iron, manganese and zinc of exclusively-breast-fed Finnish infants during the 3 months of lactation $(\mathrm{mg} / \mathrm{kg}$ per $d)$

Month of age ...

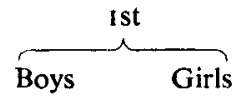

$\mathrm{Cu}$

Median

Minimum

Maximum

$\mathrm{Fe}$

Median

Minimum

Maximum

Mn

Median

Minimum

Maximum

$\mathrm{Zn}$

Median

Minimum

Maximum

\subsection{0}

0.060

0.130

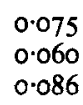

\subsection{3}

0.063

0.150

0.075

0.062

0.100

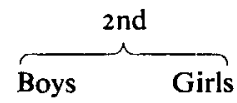

$\overbrace{\text { Boys }}^{\text {3rd }} \overbrace{\text { Girls }}^{\text {rd }}$

0.053

0.040

0.073

\subsection{1}

0.025

0.053

$\begin{array}{ll}0.044 & 0.040 \\ 0.030 & 0.019 \\ 0.049 & 0.048\end{array}$

\subsection{4}

0.045

0.100

\subsection{5}

0.039

0.082

\subsection{9}

0.030

0.086

0.047

0.035

0.076

$\begin{array}{llllll}0.0009 & 0.0009 & 0.0006 & 0.0005 & 0.0006 & 0.0004 \\ 0.0006 & 0.0005 & 0.0004 & 0.0003 & 0.0005 & 0.0004 \\ 0.0024 & 0.0011 & 0.0011 & 0.0009 & 0.0018 & 0.0009 \\ & & & & & \\ 0.440 & 0.350 & 0.250 & 0.190 & 0.150 & 0.140 \\ 0.310 & 0.240 & 0.150 & 0.130 & 0.140 & 0.080 \\ 0.800 & 0.650 & 0.430 & 0.390 & 0.400 & 0.270\end{array}$

Table 4. The average intakes $(\mathrm{mg} / \mathrm{kg}$ per $d$ ) of copper, iron, manganese and zinc of healthy, exclusively-breast-fed Finnish infants during the 1 st 3 months of life

\begin{tabular}{|c|c|c|c|c|c|c|}
\hline $\mathrm{Cu}$ & $\mathrm{Fe}$ & Mn & $\mathrm{Zn}$ & $n$ & $\begin{array}{l}\text { Stage of } \\
\text { lactation }\end{array}$ & Reference \\
\hline- & $0.12^{*}$ & - & - & 2 & 2nd week & Maurer et al. (1934) \\
\hline $0.138^{*}$ & - & - & - & 6 & Ist month & Kleinbaum (1962) \\
\hline $0.096 \dagger$ & $0.075^{\dagger}$ & - & $0.575 \dagger$ & 10 & 5th-8th day & Cavell \& Widdowson (1964) \\
\hline- & - & $0.0028^{*}$ & $\ldots$ & - & Ist month & McLeod \& Robinson (1972) \\
\hline - & - & $0.0025^{*}$ & - & - & 3rd month & \\
\hline 0.050 & 0.050 & - & 0.350 & - & Ist-3rd month & Picciano \& Guthrie (1976) \\
\hline 0.030 & 0.050 & - & 0.220 & 26 & 3rd month & Picciano \& Deering (1977) \\
\hline 0.075 & 0.075 & 0.0009 & 0.420 & 23 & Ist month & Present study \\
\hline 0.051 & 0.055 & 0.0006 & 0.215 & 18 & 2nd month & \\
\hline 0.043 & 0.048 & 0.0005 & 0.150 & 14 & 3rd month & \\
\hline
\end{tabular}

\section{RESULTS}

At birth and during the Ist and 2nd month there were no differences in height and weight between girls and boys, but in the 3rd month the boys were heavier (Table I).

The trace element concentrations of breast milk for the lactation period of 6 months given in this series of studies (Siimes et al. 1979; Vuori, 1979; Vuori \& Kuitunen, 1979) have been recalculated and the results are here given related to the energy content of breast milk (Table 2).

The intakes of $\mathrm{Cu}, \mathrm{Fe}, \mathrm{Mn}$ and $\mathrm{Zn}$, when expressed per kg weight, were found to depend on the stage of lactation (Table 3). The average daily intakes, when calculated per infant at 1,2 and 3 months of age respectively, were approximately: $\mathrm{Cu} 0.31,0.26$ and $0.25 \mathrm{mg}$; Fe $0.3 \mathrm{I}, 0.28$ and $0.27 \mathrm{mg}$; Mn 4,3 and $3 \mu \mathrm{g} ; \mathrm{Zn} \mathrm{I} \cdot 8, \mathrm{I} \cdot \mathrm{I}$ and $0.9 \mathrm{mg}$. 
Previously-reported values for trace element intakes for healthy breast-fed infants have been listed in Table 4. To render the comparison with the present study easier, our results for the two sexes have been combined.

\section{DISCUSSION}

The growth of the present group of infants corresponded to the normal growth of Finnish infants (Bäckström \& Kantero, 1971). In the 3rd month the average weight of the boys was approximately $400 \mathrm{~g}$ lower than that reported previously, but the difference was not statistically significant. The reference norms of Finnish infants are, however, almost 20 years old and also include bottle-fed infants (Bäckström \& Kantero, 1971).

Usually test-weighing has been used when determining the amount of milk ingested and the trace element intakes (Kleinbaum, I962; Cavell \& Widdowson, 1964; Picciano \& Deering, 1977), but values calculated on the basis of average food intake have also been given (McLeod \& Robinson, 1972; Picciano \& Guthrie, 1976). Some aspects must be emphasized when comparing the present results with previously-reported values (Table 4): the varying units of intake have been converted to the same unit, and some results of previous studies have been recalculated. For example Cavell \& Widdowson (I964) studied ten infants at $5^{-8} \mathrm{~d}$ of age and originally gave mean intakes. However, the ranges for intakes were wide and skewed towards lower values: for Fe the intake ranged from 0.047 to 0.302 $\mathrm{mg} / \mathrm{kg}$ per $\mathrm{d}$ and the given mean was $0.100 \mathrm{mg} / \mathrm{kg}$ per $\mathrm{d}$. A more precise average value in this instance would be the median which was $0.075 \mathrm{mg} / \mathrm{kg}$ per $\mathrm{d}$.

Official recommendations for the trace element intakes of infants under 6 months of age have been given only for $\mathrm{Zn}$ and $\mathrm{Fe}: 3$ and $5 \mathrm{mg} / \mathrm{d}$ respectively, corresponding to approximately 0.50 and $0.83 \mathrm{mg} / \mathrm{kg}$ per d (Food and Nutrition Board, I973). The Cu intake of $0.080 \mathrm{mg} / \mathrm{kg}$ per $\mathrm{d}$ is tentatively proposed to be sufficient, but no values have been given for Mn intake (WHO, Expert Committee on Trace Elements in Human Nutrition, 1973).

As remarked by Picciano \& Guthrie (1976) and Johnson \& Evans (1978) the true trace element intakes of breast-fed infants are below these recommendations; a finding also noted in the present study. However, it has been shown that breast-fed infants can maintain good Fe balance up to the age of 6 months (Saarinen et al. 1977). This is due to the exceptionallyhigh bioavailability of breast-milk Fe, which in some instances can be up to I.00 (Maurer et al. 1934; McMillan et al. 1976; Saarinen et al. 1977). Also the bioavailability of breastmilk $\mathrm{Zn}$ has recently been reported to be high. In an experiment with adult rats, $\mathrm{Zn}$ was absorbed more efficiently from breast milk than from milk formulas, the absorption being approximately 0.60 , but the authors estimate the absorption to be approximately $0.80-0.85$ in human infants (Johnson \& Evans, 1978).

The present values for trace element intakes agree well with those of previous studies of exclusively-breast-fed infants, although different methods for determining the intakes have been used; only the Mn intake is lower (Table 4). The value for Mn intake given by McLeod \& Robinson (1972) was calculated on the assumption that Mn content of breast milk is constant during lactation. These authors used the mean value from ten analyses of breast milk derived from the ist week of lactation. The Mn concentration of breast milk from New Zealand women seems to be higher (McLeod \& Robinson, 1972) than that reported elsewhere (Vuori, 1979) and moreover, a decrease in the Mn concentration has been shown to take place during the Ist months of lactation (Vuori, 1979).

All infants in the present study were healthy and weight and height gains were typical of Finnish infants (Bäckström \& Kantero, I97I). Hence the intake of trace elements seems to be sufficient, although it is below the given recommendations (Food and Nutrition Board, 1973; WHO Expert Committee on Trace Elements in Human Nutrition, 1973). Another question is the proper concentration of trace elements in different formulas because 
the bioavailability of at least $\mathrm{Fe}$ and $\mathrm{Zn}$ is lower (Saarinen et al. 1977; Johnson \& Evans, 1978) and thus the concentration and intake must be correspondingly higher.

The author thanks Drs P. Kuitunen and M. A. Siimes for their constructive criticism. The work was supported by a grant from the Yrjö Jahnsson Foundation, Helsinki, Finland.

\section{REFERENCES}

Bäckström, L. \& Kantero, R.-L. (1971). Acta paediat. scand. Suppl. 220, 9.

Cavell, P. A. \& Widdowson, E. M. (1964). Archs Dis. Childh. 39, 496.

Fomon, S. J. (1974). Infant Nutrition, 2nd ed. Philadelphia: W. B. Saunders Co.

Food and Nutrition Board, National Academy of Sciences-National Research Council (1973). Nutr. Rev. 3r, 394 .

Hall, B. (1975). Lancet i, 779.

Hytten, F. E. (I954). Br. med. J. i, 179.

Johnson, P. E. \& Evans, G. W. (1978). Am. J. clin. Nutr. 31, 416.

Kleinbaum, H. (1962). Z. Kinderheilkd. 87, 10I.

McLeod, B. E. \& Robinson, M. F. (1972). Br. J. Nutr. $27,229$.

McMillan, J. A., Landaw, S. A. \& Oski, F. A. (1976). Pediatrics, Springfield 58, 686.

Maurer, S., Greengard, J., Curtis, W. L. \& Klüver, C. ( 1934). J. Pediat. 4, 365.

Picciano, M. F. \& Deering, R. H. (1977). Fedn Proc. Fedn Am. Socs exp. Biol. 36, 1175.

Picciano, M. F. \& Guthrie, H. A. (1976). Am. J. clin. Nutr. 29, 242.

Saarinen, U. M., Siimes, M. A. \& Dallman, P. R. (1977). J. Pediat. 91, 36.

Siimes, M. A., Vuori, E. \& Kuitunen, P. (1979). Acta paediat. scand. 68, 29.

Vuori, E. (1979). Acta paediat. scand. 68, 571.

Vuori, E. \& Kuitunen, P. (1979). Acta paediat. scand. 68, 33.

WHO Expert Committee on Trace Elements in Human Nutrition (1973). Tech. rep. Ser. Wld Hlih Org. no. 532 . 